\title{
Reconstruction of soil pH by dendrochemistry of Masson pine at two forested sites in the Pearl River Delta, South China
}

\author{
Yuan Wen KuAnG*, Da Zhi Wen, Guo Yi ZHou, Guo Wei CHU, Fang Fang Sun, Jiong Li \\ Institute of Ecology, South China Botanical Garden, the Chinese Academy of Sciences, Guangzhou, 510650 China
}

(Received 14 May 2008; accepted 5 August 2008)

Keywords:

dendrochemistry /

tree ring /

soil pH reconstruction /

Masson pine (Pinus massoniana) /

Pearl River Delta

\begin{abstract}
- Soil acidification is a global concern. Base cation ( $\mathrm{Ca}, \mathrm{Mg}, \mathrm{Mn}$ and $\mathrm{Al}$ ) concentrations, as well as their molar ratios, were measured in tree rings of Masson pines (Pinus massoniana L.) from Dinghushan and Xiqiaoshan to reconstruct the historical changes in soil acidification in the Pearl River Delta, south China.

- In Dinghushan, Ca and Mn xylem concentrations yielded significant correlations with the higher soil $\mathrm{pHs}$, and $\mathrm{Ca}$ and $\mathrm{Mg}$ with the lower soil $\mathrm{pHs}$. In Xiqiaoshan, only xylem Mn concentration correlated significantly with the soil $\mathrm{pH}$ in both layers. Significant correlations between xylem molar ratios and soil $\mathrm{pH}$ were revealed for $\mathrm{Ca} / \mathrm{Mn}, \mathrm{Mg} / \mathrm{Mn}, \mathrm{Mn} / \mathrm{Al}$ and $\mathrm{Ca} / \mathrm{Al}$ in the upper soils and for the same ratios except for $\mathrm{Ca} / \mathrm{Al}$ in the deeper soils in Dinghushan. The same correlations were revealed for $\mathrm{Ca} / \mathrm{Mn}, \mathrm{Mg} / \mathrm{Mn}$ and $\mathrm{Mn} / \mathrm{Al}$ at both depths in Xiqiaoshan.

- Soil pHs at $0-10 \mathrm{~cm}$ and $10-40 \mathrm{~cm}$ depths at the study sites were reconstructed by the molar ratios of $\mathrm{Mg} / \mathrm{Mn}$ and $\mathrm{Ca} / \mathrm{Mn}$ in the xylem of Masson pines, respectively.

- Cation molar ratios in the xylem of Masson pine were superior to the single $\mathrm{Ca}, \mathrm{Mg}, \mathrm{Mn}$ and $\mathrm{Al}$ for soil acidity reconstruction in the Delta of China.
\end{abstract}

Résumé - Reconstruction du pH du sol par dendrochimie chez Pinus massoniana dans deux stations forestières du delta de la Pearl River, dans le sud de la Chine.

- L'acidification du sol est un phénomène important à l'échelle mondiale. Les concentrations en cations ( $\mathrm{Ca}, \mathrm{Mg}, \mathrm{Mn}$ et $\mathrm{Al}$ ) aussi bien que leurs rapports molaires dans les cernes des pins (Pinus massoniana L.) de Dinghushan et Xiqiaoshan ont été mesurées pour reconstruire les changements historiques d'acidification du sol dans le delta de la Pearl River, dans le sud de la Chine.

- À Dinghushan, les concentrations en Ca et Mn du xylème présentent des corrélations significatives avec les $\mathrm{pH}$ de la partie supérieure du sol, $\mathrm{Ca}$ et $\mathrm{Mg}$, avec les $\mathrm{pH}$ de la partie inférieure du sol. À Xiqiaoshan, seule la concentration en $\mathrm{Mn}$ du xylème est corrélée significativement avec les $\mathrm{pH}$ du sol dans les deux horizons. Des corrélations significatives entre rapports molaires dans le xylème et les $\mathrm{pH}$ du sol ont été mises en évidences pour $\mathrm{Ca} / \mathrm{Mn}, \mathrm{Mg} / \mathrm{Mn}, \mathrm{Mn} / \mathrm{Al}$ et $\mathrm{Ca} / \mathrm{Al}$ dans les parties supérieures des sols et pour les mêmes rapports sauf $\mathrm{Ca} / \mathrm{Al}$ dans les parties profondes des sols à Dinghushan. Des corrélations semblables ont été révélées pour $\mathrm{Ca} / \mathrm{Mn}, \mathrm{Mg} / \mathrm{Mn}$ et $\mathrm{Mn} / \mathrm{Al}$ dans les deux profondeurs à Xiqiaoshan.

- Les pH du sol à $0-10 \mathrm{~cm}$ et $10-40 \mathrm{~cm}$ de profondeur dans les sites d'étude ont été reconstruits à partir des rapports molaires de $\mathrm{Mg} / \mathrm{Mn}$ et $\mathrm{Ca} / \mathrm{Mn}$ dans le xylème des pins. Les rapports molaires des cations dans le xylème des pins étaient supérieurs au seul $\mathrm{Ca}, \mathrm{Mg}, \mathrm{Mn}$ et $\mathrm{Al}$ pour la reconstruction de l'acidité du sol dans le Delta de la Chine.

\section{INTRODUCTION}

Tree rings are good recorders of environmental changes. Dendroanalysis of coniferous species has been frequently used

*Corresponding author: kuangyw@scbg.ac.cn to examine specific effects of environmental changes on ring width and to investigate the responses of trees to those changes (Campelo et al., 2007; Muzika et al., 2004; Park et al., 2006). Dendrochemistry has provided a way to detect the long-term changes in environmental quality, since chemical variations can be detected in tree rings and be assigned to a distinct 
time in the past. Therefore, temporal changes in chemistry in tree rings can be used as a suitable indicator for historical and ongoing processes in the rooting zone of soils (Augustin et al., 2005; Berger et al., 2004; Ferretti et al., 2002; Poszwa et al., 2003). Coniferous species, as well as broadleaved ones, have been widely used to reveal the impacts of pollution on forest health (Kuang et al., 2007; Kurczyńska et al., 1997; Yilmaz and Zengin 2004), and have frequently been selected as surrogates for reconstructing the history of environmental pollution, such as the emission of heavy metals (Baes III and Mclaughlin 1984; Orlandi et al., 2002; Padilla and Anderson 2002; Punshon et al., 2005), the deposition of nitrogen (Saurer et al., 2004) and the changes in soil chemistry (Augustin et al., 2005; Berger et al., 2004; Guyette et al., 1992).

Soil acidification is a globally important issue which causes base cation loss and phytotoxic element increase, particularly $\mathrm{Al}$, in the soil. Concentrations of xylem divalent cations, such as $\mathrm{Mn}, \mathrm{Ca}$ and $\mathrm{Mg}$, which are bound to sap-conducting tissue in tree boles after being absorbed through the xylem stream (Ferguson and Bollard, 1976) are influenced by the changes in soil acidity (DeWalle et al., 1991, 1999; Guyette et al., 1992; Kashuba-Hockenberry and DeWalle, 1994). Thus, the radial variations in base cations in tree rings offer the potential for detecting the historical changes in the soil chemistry where the tree grew, and could overcome the difficulty in evaluating the long-term changes in soil $\mathrm{pH}$ for lack of historical monitoring data in most areas.

The Pearl River Delta, located in the Guangdong province of south China, has undergone increasing urbanization and industrialization in the last few decades since China's opening and reforming policy in the 1980s. Environmental pollution and ecosystem deterioration have been of increasing concern in the Delta (Huang et al., 2003). Acid rain has been considered the major environmental problem since the 1980s (Jin, 2002) and has caused a wide range of chemical changes in poorly buffered forest soils via acceleration of base cation leaching (Wen et al., 2000) and accumulation of soluble and available Al (Liu et al., 2003) in the soil. Inputs of acidic agents (mainly $\mathrm{SO}_{4}^{2-}$ ) have persisted well above the background levels in the area during the last two decades (Xie et al., 2002). However, long-term changes in soil chemistry have not been analyzed until now for the lack of long-term monitoring data, though local forest decline in the Delta has been well documented (Hu and Su, 1999; Jin, 2002; Luo et al., 2001; Wen et al., 2006).

Masson pine (Pinus massoniana L.) is a ubiquitously distributed tree species across subtropical China. High sensitivity of Masson pine to acid deposition (Han and Liang, 2001) makes it a good candidate for dendrochemical analysis. The purposes of this study were: (1) to determine the relationships between the recent xylem cation concentrations (their molar ratios) and the actually observed soil pHs; (2) to confirm the best index among the xylem cations and/or molar cation ratios as bioindicators of soil acidification in the Pearl River Delta; and (3) to reconstruct the chronology of soil $\mathrm{pH}$ change in the studied sites based on the temporal changes in the xylem cations.

\section{MATERIALS AND METHODS}

\subsection{Study sites}

Two mixed forest sites (at least $60 \%$ broadleaf trees) were selected in Dinghushan $\left(112^{\circ} 34^{\prime} \mathrm{E}, 23^{\circ} 10^{\prime} \mathrm{N}\right)$, a natural reserve located in Zhaoqing city and Xiqiaoshan $\left(112^{\circ} 56^{\prime} \mathrm{E}, 23^{\circ} 55^{\prime} \mathrm{N}\right)$, a national forest park located in Foshan city. Both sampling sites are characterized as low-subtropical monsoon climate with laterite soils developed from granite and sand shale. The annual mean air temperature and total precipitation averaged from 1970 to 2000 were $22.3^{\circ} \mathrm{C}$ and $1671 \mathrm{~mm}$ in Dinghushan, and $22.5^{\circ} \mathrm{C}$ and $1618 \mathrm{~mm}$ in Xiqiaoshan, respectively (Kuang et al., 2008). The dominant broadleaf species are Randia canthioides and Schima superba in Dinghushan, and Schefflera octophylla and Schima superb in Xiqiaoshan.

\subsection{Sampling and analytical methods}

Five mature Masson pines at each site were selected for sampling. The sample trees were healthy-looking and open-grown without suppression by shading. The selected trees were wholly harvested in late autumn 2002, and discs of about $20 \mathrm{~cm}$ in thickness were cut off from the base of each tree. The discs were then labeled and brought to the laboratory for dendrochronological and chemical measurements. In the laboratory, all the discs were air-dried and polished using a sandpapering machine fitted with a silicium-carbide band. Annual growth rings of each disc were dated by the WinDendro system (Canada) and ring widths were measured at an accuracy of $0.01 \mathrm{~mm}$. Halfdecade xylems representing 5-year growth intervals, from the pith to the outer part of each disc, were carefully split out in sequence with an electric micro-chisel. For the most recent xylems, only 2-year growth intervals (2001-2002) were split as one sample. The wood chips were dried at $65{ }^{\circ} \mathrm{C}$ and ground to pass a $0.1-\mathrm{mm}$ sieve. Wood powder, about $0.5000 \mathrm{~g}$, was placed into the digestion vessels and digested with $10 \mathrm{~mL}$ concentrated nitric acid in the sealed Multiwave 3000 sample preparing system (Anton paar, Austria). The solution was then diluted to a final volume of $50 \mathrm{~mL}$ with distilled, deionized water. Cations ( $\mathrm{Ca}, \mathrm{Mg}, \mathrm{K}, \mathrm{Mn}$ and $\mathrm{Al}$ ) were determined by inductively-coupled plasma optical emission spectroscopy (ICPOES, Optima 2000DV, PerkinElmer, USA). According to Smith and Shortle (1996), the half-decade mean values for the same cation of all five trees per site were treated as one replicate.

Prior to tree harvest, soil was collected from east, south, west and north directions $1 \mathrm{~m}$ away from each selected tree. The litter layer was removed before soil sampling. The soil was divided into upper $(0-10 \mathrm{~cm})$ and lower $(10-40 \mathrm{~cm})$ depths, in which the roots of the pine tree were mainly distributed. Soil samples collected from the four directions beneath each tree were pooled by depth, stored in labeled plastic bags, brought to the laboratory, and were air-dried and sieved through a $2-\mathrm{mm}$ sieve for chemical analysis. Ten grams of soil sample were mixed with $10 \mathrm{~mL}$ of deionized water. The solution was then stirred at 10-min intervals, and the acidity was measured after 30 min with a glass $\mathrm{Ag} / \mathrm{AgCl}$ combination electrode with a $\mathrm{KCl}$ reference electrode. Exchangeable $\mathrm{Ca}, \mathrm{Mg}, \mathrm{Mn}$ and $\mathrm{Al}$ were extracted using $1 \mathrm{M}$ ammonium acetate $\left(\mathrm{CH}_{3} \mathrm{COONH}_{4}\right)$ following the methods of Dong (1996) and measured by ICP-OES (Optima 2000DV). Base cation saturation (BS) and cation exchangeable capacity (CEC) of soils at the different depths were obtained. A paired sample $t$-test was performed to compare the difference in the soil parameters between the sites at the confidence level of $95 \%$. 
Table I. Mean contents of exchangeable $\left(\mathrm{CH}_{3} \mathrm{COONH}_{4}\right) \mathrm{Ca}, \mathrm{Mg}, \mathrm{Mn}$ and $\mathrm{Al}\left(\mathrm{mmolkg}^{-1}\right)$, and $\mathrm{pH}\left(\mathrm{H}_{2} \mathrm{O}\right)$ in the forest soil. Paired sample tests were performed to test differences between 5 pairs of samples in Dinghushan and Xiqiaoshan. Level of significance is shown as: ns: not significant; $* P<0.05$; $* * P<0.01$. CEC: base cation saturation; BS: cation exchangeable capacity. Data in brackets after the $\mathrm{pH}$ values are the actually observed soil $\mathrm{pH}$ ranges at each site.

\begin{tabular}{|c|c|c|c|c|c|c|c|}
\hline \multirow[t]{2}{*}{ Site } & \multirow[t]{2}{*}{$\mathrm{pH}\left(\mathrm{H}_{2} \mathrm{O}\right)$} & \multirow[t]{2}{*}{ BS $(\%)$} & \multicolumn{4}{|c|}{$\begin{array}{l}\text { Exchangeable cations } \\
\left(\mathrm{mmolkg}^{-1}\right)\end{array}$} & \multirow[t]{2}{*}{ CEC } \\
\hline & & & $\mathrm{Ca}$ & $\mathrm{Mg}$ & $\mathrm{Mn}$ & $\mathrm{Al}$ & \\
\hline \multicolumn{8}{|c|}{ Upper soil $(0-10 \mathrm{~cm})$} \\
\hline Dinghushan & $3.81(3.59-3.93)$ & 9.18 & 6.73 & 0.68 & 0.10 & 8.68 & 12.62 \\
\hline Xiqiaoshan & $3.88(3.68-3.96)$ & 10.94 & 9.48 & 1.39 & 4.95 & 4.11 & 15.05 \\
\hline$p$ & ns & ns & $*$ & $*$ & $* *$ & $*$ & ns \\
\hline \multicolumn{8}{|c|}{ Lower soil $(10-40 \mathrm{~cm})$} \\
\hline Dinghushan & $4.01(3.91-4.09)$ & 13.33 & 5.46 & 0.18 & 0.18 & 7.54 & 9.28 \\
\hline Xiqiaoshan & $4.22(4.11-4.33)$ & 15.83 & 6.28 & 0.85 & 3.82 & 2.88 & 10.84 \\
\hline$p$ & ns & ns & ns & $* *$ & $* *$ & $*$ & ns \\
\hline
\end{tabular}

\subsection{Calculation of soil pH from tree-ring chemistry}

Normalizing for concentration declines or other fluctuations by calculating element ratios should give a much better perspective of how the chemistry of the transpiration stream has changed over time in a given tree, as well as allowing trends in trees of different ages to be directly compared (Bondietti et al. 1989). Hence, according to the method described by Berger et al. (2004), linear correlations were performed for all cations and their molar ratios ( $\log _{10}$-transformed) of the last two-year xylem with actual soil $\mathrm{pH}$ data at different depths ( 5 trees per site), respectively. In the second step, those parameters (cation concentrations and/or molar ratios) with significant correlations were used as input variables for the performance of stepwise regressions to select the best predictor of soil $\mathrm{pH}$ at different depths. Finally, the $\mathrm{pH}$ values assigned at a distinct time were calculated by the regression equations based on the xylem values, respectively.

\section{RESULTS AND DISCUSSION}

\subsection{Soil chemistry at the forested sites}

Soil chemistry at the two sites is summarized in Table I. Soil acidity (pH), BS and CEC of soils within the same depth did not differ significantly between Dinghushan and Xiqiaoshan. According to Neubauer (2000), $\mathrm{pH}$ and CEC are the best indicators for soil chemistry because they are preferentially influenced by geochemical cycles (soil formation) and not like carbon, by biochemical cycles. However, exchangeable $\mathrm{Ca}, \mathrm{Mg}$ and $\mathrm{Mn}$ of the mineral soil in the $0-10 \mathrm{~cm}$ depth in Dinghushan were significantly lower than those in Xiqiaoshan, though these cations decreased with increasing soil depth. Similarly, significant differences in exchangeable $\mathrm{Mg}$ and $\mathrm{Mn}$ between the sites were also observed in the $10-40 \mathrm{~cm}$ depth. Generally, Dinghushan was much poorer in exchangeable $\mathrm{Ca}, \mathrm{Mg}$ and $\mathrm{Mn}$ than Xiqiaoshan was, but it was the opposite in exchangeable Al, suggesting that soil in Dinghushan was more susceptible to acidification and aluminum toxicity. This result was in disagreement with Taylor (1988), who proposed
Table II. Significant linear correlation coefficients between soil actual $\mathrm{pH}\left(\mathrm{H}_{2} \mathrm{O}\right)$ and logarithmic dendrochemical parameters of the recent 2-year xylems of Masson pine in Dinghushan and Xiqiaoshan. Other parameters, such as concentration of $\mathrm{Al}$, and molar ratios of $\mathrm{Ca} / \mathrm{Mg}$ and $\mathrm{Mg} / \mathrm{Al}$, could not be found to be significantly correlated with soil $\mathrm{pH}$ for any of the given soil depths. Significance levels as in Table I. $N=5$ trees per site.

\begin{tabular}{lccccccc}
\hline Site & $\mathrm{Ca}$ & $\mathrm{Mg}$ & $\mathrm{Mn}$ & $\mathrm{Ca} / \mathrm{Mn}$ & $\mathrm{Ca} / \mathrm{Al}$ & $\mathrm{Mg} / \mathrm{Mn}$ & $\mathrm{Mn} / \mathrm{Al}$ \\
\hline \multicolumn{8}{c}{ Top mineral soil $(0-10 \mathrm{~cm})$} \\
Dinghushan & $0.82^{*}$ & $\mathrm{~ns}$ & $0.75^{* *}$ & $0.85^{* *}$ & $0.66^{*}$ & $0.89^{*}$ & $0.81^{* *}$ \\
Xiqiaoshan & $\mathrm{ns}$ & $\mathrm{ns}$ & $0.67^{*}$ & $0.71^{*}$ & $\mathrm{~ns}$ & $0.89^{*}$ & $0.70^{*}$ \\
\hline \multicolumn{8}{c}{ Deeper soil $(10-40 \mathrm{~cm})$} \\
Dinghushan & $0.74^{*}$ & $0.78^{*}$ & $\mathrm{~ns}$ & $0.78^{*}$ & $\mathrm{~ns}$ & $0.87^{*}$ & $0.75^{*}$ \\
Xiqiaoshan & $\mathrm{ns}$ & $\mathrm{ns}$ & $0.76^{*}$ & $0.84^{*}$ & $\mathrm{~ns}$ & $0.67^{*}$ & $0.72^{*}$ \\
\hline
\end{tabular}

that less $\mathrm{Al}$ would be expected to be exchangeable in the 0 $10 \mathrm{~cm}$ depth due to the ability of organic matter to bind Al. Low exchangeable cations in the soils at the sites, in particular in Dinghushan, indicated low acid buffering capacity or rapid acceleration of base cation leaching. Although whether Xiqiaoshan had experienced accelerated base cation leaching and soil acidification resulting from high inputs of acid anions in the Delta (Guan and Huang, 2003; Xie et al., 2002) remained unknown, soil acidification was well documented at the two sites (Liu et al., 2003; Wen et al., 2000). In fact, industries including large-scale ceramic manufacturing, electroplating, and aluminum- and copper-refining factories have been developed rapidly around the study sites since the 1980s, and visible damage in the local vegetation resulting from the industrial emissions has been reported recently (Wen et al., 2006).

\subsection{Correlations between xylem cations and soil pH values}

The results of linear regressions derived from the recent xylem cation concentrations (their molar ratios, $\log _{10^{-}}$ transformed) and the present soil $\mathrm{pH}$ values are listed in Table II. In the topsoil, correlation of the recent xylem cation concentrations with actual soil $\mathrm{pHs}$ yielded significant results for $\mathrm{Ca}$ and $\mathrm{Mn}$ in Dinghushan, and only for $\mathrm{Mn}$ in Xiqiaoshan. However, in the deeper soils, these correlations were significant for $\mathrm{Ca}$ and $\mathrm{Mg}$ in Dinghushan, and still only for $\mathrm{Mn}$ in Xiqiaoshan. Significant correlations between xylem molar ratios and soil $\mathrm{pHs}$ were revealed for $\mathrm{Ca} / \mathrm{Mn}, \mathrm{Mg} / \mathrm{Mn}, \mathrm{Mn} / \mathrm{Al}$ and $\mathrm{Ca} / \mathrm{Al}$ in the topsoils and for the same ratios except for $\mathrm{Ca} / \mathrm{Al}$ in the deeper soils in Dinghushan. Unlike in Dinghushan, significant correlations in Xiqiaoshan were revealed for $\mathrm{Ca} / \mathrm{Mn}$, $\mathrm{Mg} / \mathrm{Mn}$ and $\mathrm{Mn} / \mathrm{Al}$ in both depths. Hence, the stepwise regression equations, developed by those significant parameters for Dinghushan and Xiqiaoshan at different soil depths, respectively, were as follows (level of significance of adjusted $R^{2}$ is shown as ${ }^{*} P<0.05$; $\left.{ }^{* *} P<0.01\right)$ :

$$
\begin{aligned}
& 0-10 \mathrm{~cm} \\
& \text { Dinghushan : } \mathrm{pH}=3.470+0.694 \times\left[\log _{10}(\mathrm{Mg} / \mathrm{Mn})\right] \\
& \left(\operatorname{adj} . R^{2}=0.92^{* *}\right)
\end{aligned}
$$


Xiqiaoshan : $\mathrm{pH}=3.522+0.598 \times\left[\log _{10}(\mathrm{Ca} / \mathrm{Mn})\right]$

$$
\left(\operatorname{adj} . R^{2}=0.74^{*}\right)
$$

$$
\begin{aligned}
& 10-40 \mathrm{~cm} \\
& \text { Dinghushan : } \mathrm{pH}=3.680+0.335 \times\left[\log _{10}(\mathrm{Mg} / \mathrm{Mn})\right] \\
& \qquad\left(\operatorname{adj} . R^{2}=0.76 *\right)
\end{aligned}
$$

Xiqiaoshan : $\mathrm{pH}=3.803+0.249 \times\left[\log _{10}(\mathrm{Ca} / \mathrm{Mn})\right]$

$$
\left(\operatorname{adj} . R^{2}=0.65 *\right)
$$

In Dinghushan, soil pHs were best explained (positive relationship) by only one remaining independent variable, the xylem $\mathrm{Mg} / \mathrm{Mn}$ ratio, at both depths. In Xiqiaoshan, soil pHs were explained by only the xylem $\mathrm{Ca} / \mathrm{Mn}$ ratio at both depths. Indeed, the comparison of bivariate correlation showed that the xylem $\mathrm{Mg} / \mathrm{Mn}$ ratio $(0-10 \mathrm{~cm}$ depth soil) and the $\mathrm{Ca} / \mathrm{Mn}$ ratio (10-40 cm depth soil) yielded the highest correlation coefficients (Tab. II). The correlations implied that xylem cation molar ratios of Masson pine were superior to the single $\mathrm{Ca}$, $\mathrm{Mg}, \mathrm{Mn}$ and $\mathrm{Al}$ in soil acidity reconstruction in the Delta. These results disagree with those of others who stated that single cation concentrations (e.g., $\mathrm{Mn}$ and $\mathrm{Ba}$ ) in the xylem were highly correlated with soil $\mathrm{pH}$ and could be used as monitors to differentiate changes in soil acidity due to sulfur deposition (Guyette and Cutter, 1994; Guyette et al., 1992). Recently, the concentration of $\mathrm{Mn}$ in tree rings of Norway spruce was also implied to be an indicator of soil chemistry changes in the past (Augustin et al., 2005). In this study, the highest correlations of molar rations with soil $\mathrm{pHs}$ coincided with the results of Kogelmann and Sharpe (2006), who found significant correlations between xylem $\mathrm{Mg} / \mathrm{Mn}$ or $\mathrm{Ca} / \mathrm{Mn}$ and soil $\mathrm{pH}$.

Though Bondietti et al. (1989) proposed the use of molar ratios in tree rings as an indicator of the impact of atmospheric deposition on forests, Cronan and Grigal (1995) argued that there was little direct experimental evidence in support of using xylem $\mathrm{Ca} / \mathrm{Al}$ ratios to detect the effects of atmospheric deposition, and further debated that extremely low $\mathrm{Al}$ relative to high $\mathrm{Ca}$ or $\mathrm{Mg}$ concentrations observed in the xylem might cause computational problems with such ratios. DeWalle et al. (1999) suggested that $\mathrm{Ca} / \mathrm{Mn}$ and $\mathrm{Mg} / \mathrm{Mn}$ molar ratios in the xylem may be more useful for the detection of soil acidification effects than $\mathrm{Ca} / \mathrm{Al}$, because sapwood concentrations of $\mathrm{Ca}$ and $\mathrm{Mg}$ were higher, $\mathrm{Mn}$ concentrations were lower, and $\mathrm{Al}$ did not differ in less acidic compared with acidic soils for several tree species. The results of stepwise regressions in our study confirmed the lack of efficacy of application of the xylem $\mathrm{Ca} / \mathrm{Al}$ ratio for detection of soil $\mathrm{pH}$ despite its significant correlation with actual soil $\mathrm{pH}$ in the $0-10 \mathrm{~cm}$ depth in Dinghushan (Tab. II). In fact, the xylem $\mathrm{Ca} / \mathrm{Al}$ ratio had the smallest coefficient among the ratios with significant correlation with soil $\mathrm{pH}$ in Dinghushan (correlation coefficient = $0.66, P<0.05$, Tab. II), which again implied that the $\mathrm{Ca} / \mathrm{Al}$ ratio does not seem to be the best indicator for soil $\mathrm{pH}$ reconstruction in this study. Kogelmann and Sharpe (2006) also invalidated the use of the $\mathrm{Ca} / \mathrm{Al}$ ratio and validated the use of the $\mathrm{Mg} / \mathrm{Mn}$ ratio for detection of forest soil chemistry.

\subsection{Cations in tree rings of Masson pine}

Mean concentrations of $\mathrm{Ca}, \mathrm{Mg}, \mathrm{Mn}$ and $\mathrm{Al}$ in the five trees of Masson pine in Dinghushan and Xiqiaoshan were plotted in Figure 1. A quite surprising feature of Figure 1 was that cation patterns did not always show a steady decline from the older to the younger wood due to a declining cation binding capacity with the increasing distance from the pith. Xylem Mn had an additional peak during the observed time span in Xiqiaoshan and xylem $\mathrm{Al}$ increased in the younger wood at both sites.

Mean cation xylem concentrations of Masson pine were also calculated over all 5-year segments at the two sites (Tab. III). Calcium and $\mathrm{Mg}$ xylem concentrations in Xiqiaoshan were not significantly higher than those in Dinghushan, despite higher exchangeable $\mathrm{Ca}$ and $\mathrm{Mg}$ soil stores in the $0-10 \mathrm{~cm}$ depth in Xiqiaoshan (Tab. I). Significantly higher xylem Mn and significantly lower xylem Al in Xiqiaoshan than those in Dinghushan were in accordance with the measured exchangeable $\mathrm{Mn}$ and $\mathrm{Al}$ in all of the soil horizons (Tab. I).

Although site-specific and species-specific large variation existed in the concentrations of $\mathrm{Ca}$ and $\mathrm{Mg}$, with a majority of species showing similar patterns in sapwood and heartwood (Meerts, 2002), just as revealed in the present study, Watmough (1997) confirmed in a review that changes in chemistry in younger xylems coincided with the hypothesized changes in chemistry of poorly buffered soils resulting from acid deposition, despite the fact that radial translocation of mineral elements may be one of the factors complicating the wide application of dendrochemistry to historical environmental monitoring. He further concluded that the use of dendrochemistry was promising in environmental monitoring. The decline in $\mathrm{Ca}$ and $\mathrm{Mg}$ in recent tree rings in Masson pine in the present study was also confirmed by Bondietti et al. (1990) in red spruce and by Penninckx et al. (2001) in two structurally different species, who revealed that the decrease in xylem $\mathrm{Ca}$ and $\mathrm{Mg}$ was apparently consistent with a long-term process of soil acidification (possibly due to acid rain). The increase in $\mathrm{Al}$ in younger xylems of Masson pine was also reported by Lévy et al. (1996), who confirmed the increase was led by soil acidification. Soils in the Pearl River Delta were susceptible to acidification by atmospheric deposition and were considered as having a poor buffer capacity for acidification (Tab. I; Liu et al., 2003; Wen et al., 2000).

Half-decade concentrations of $\mathrm{Ca}, \mathrm{Mg}$ and $\mathrm{Mn}$ in Masson pine were positively correlated with each other in Dinghushan and Xiqiaoshan (Tab. IV). Xylem concentrations were significantly correlated for all analyzed cations, but not for Al (Ca: $R=0.91, P<0.01 ; \mathrm{Mg}: R=0.87, P<0.01 ; \mathrm{Mn}$ : $R=0.88, P<0.01)$ at the two sites. Hence, regional factors might play a major role in controlling temporal patterns of the cation concentrations. Our results showed that tree-ring Al was significantly negatively correlated with $\mathrm{Ca}, \mathrm{Mn}$ and Mg (Tab. IV), which coincided with a previous study (Forget and Zayed, 1995), implying that the absorption of $\mathrm{Al}$ in plants may suppress the adsorption of $\mathrm{Ca}, \mathrm{Mg}$ and $\mathrm{Mn}$. This might be partially supported by $\mathrm{Al}$ accumulation and $\mathrm{Ca}, \mathrm{Mg}$ and $\mathrm{Mn}$ 


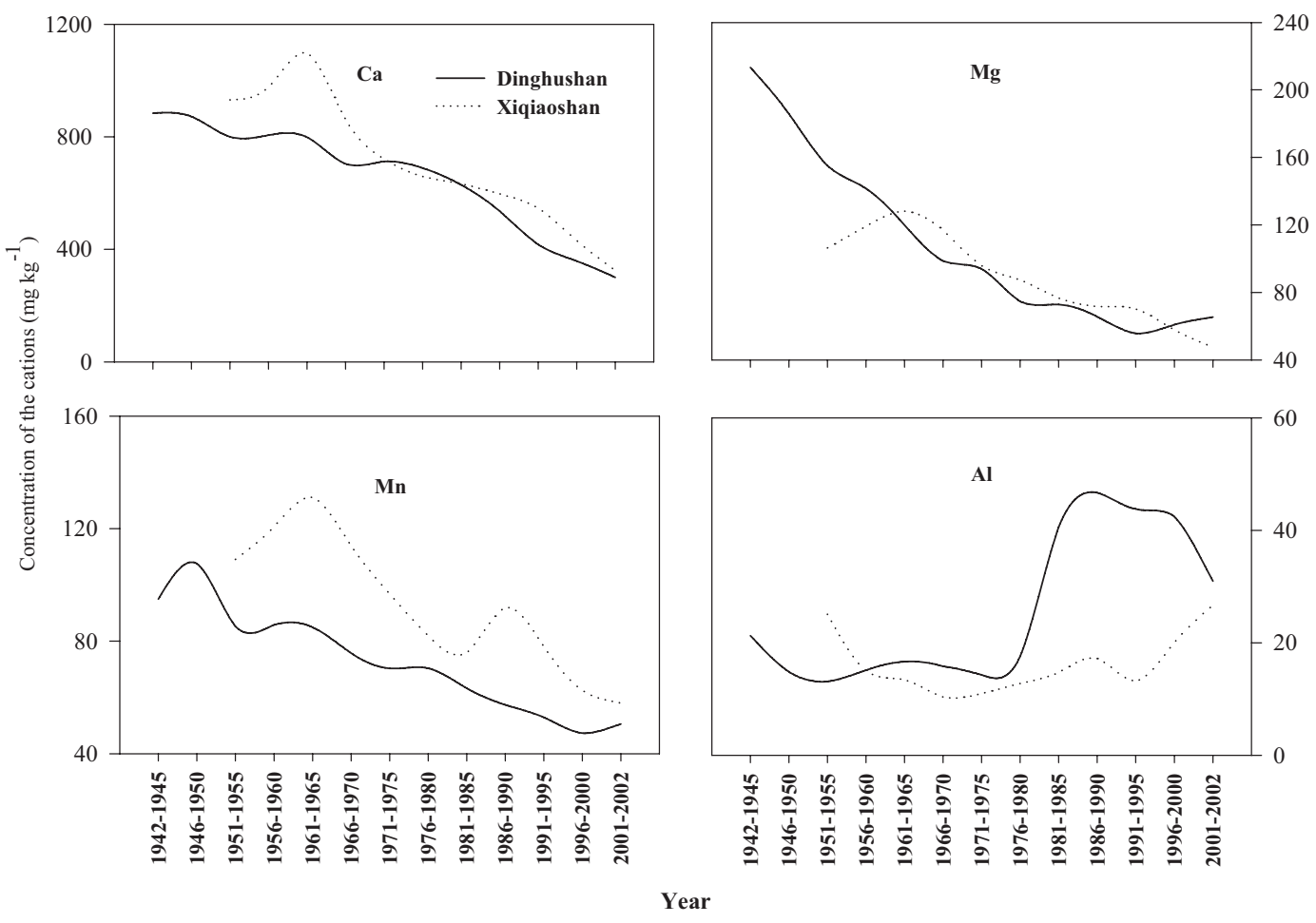

Figure 1. Mean concentrations of $\mathrm{Ca}, \mathrm{Mg}, \mathrm{Mn}$ and $\mathrm{Al}$ in the tree rings of Masson pine in Dinghushan from 1942-1945 to 2001-2002 and Xiqiaoshan from 1951-1955 to 2001-2002, respectively.

Table III. Mean cation xylem concentrations of Masson pine (average of 12 5-year segments in Dinghushan and of 10 5-year segments in Xiqiaoshan in $\mathrm{mgkg}^{-1}$ ). A one-way ANOVA was performed for each cation between sites separately $(N=12$ segments $\times 5$ trees in Dinghushan, and $N=10$ segments $\times 5$ trees in Xiqiaoshan; ns: not significant; $* P<0.05)$.

\begin{tabular}{lcccc}
\hline & $\mathrm{Ca}$ & $\mathrm{Mg}$ & $\mathrm{Mn}$ & $\mathrm{Al}$ \\
\hline Dinghushan & 654.4 & 107.9 & 72.8 & 25.6 \\
Xiqiaoshan & 707.0 & 88.8 & 92.7 & 16.3 \\
$p$ & $\mathrm{~ns}$ & $\mathrm{~ns}$ & $*$ & $*$ \\
\hline
\end{tabular}

deficiency occurring in the pine needles in Xiqiaoshan (Kuang et al., 2007).

\subsection{Reconstruction of soil $\mathrm{pH}$ from tree-ring chemistry}

Based on these equations, soil pHs were reconstructed over the last several decades at $0-10$ and $10-40 \mathrm{~cm}$ depth in Dinghushan and Xiqiaoshan, respectively, and were plotted separately for each substrate in Figure 2. In Dinghushan, the reconstructed soil pHs ranged from 3.74 to 3.97 and from 3.98 to 4.06 at $0-10 \mathrm{~cm}$ and $10-40 \mathrm{~cm}$ depth, respectively. In Xiqiaoshan, the values ranged from 3.68 to 3.75 and from 4.02 to 4.07 , respectively. These values were accurately in the ranges of the actually observed soil pHs at each site (Tab. I). Decline in the reconstructed topsoil pHs was much sharper than that of deep soil pHs. At 0-10 cm depth, the larger de-
Table IV. Correlation coefficients of $\mathrm{Ca}, \mathrm{Mg}, \mathrm{Mn}$ and $\mathrm{Al}$ in the tree rings in Dinghushan and Xiqiaoshan $(N=12$ segments $\times 5$ trees in Dinghushan, and $N=10$ segments $\times 5$ trees in Xiqiaoshan; ${ }^{* *} P<$ $0.01)$.

\begin{tabular}{lcccccc}
\hline \multirow{2}{*}{ Cation } & \multicolumn{3}{c}{ Dinghushan } & \multicolumn{3}{c}{ Xiqiaoshan } \\
\cline { 2 - 7 } & $\mathrm{Ca}$ & $\mathrm{Mg}$ & $\mathrm{Mn}$ & $\mathrm{Ca}$ & $\mathrm{Mg}$ & $\mathrm{Mn}$ \\
\hline $\mathrm{Mg}$ & $0.83^{*}$ & & & $0.98^{* *}$ & & \\
$\mathrm{Mn}$ & $0.94^{* *}$ & $0.92^{* *}$ & & $0.97^{* *}$ & $0.97^{* *}$ & \\
$\mathrm{Al}$ & $-0.76^{*}$ & $-0.64^{*}$ & $-0.77^{* *}$ & -0.38 & -0.47 & -0.39 \\
\hline
\end{tabular}

gree of soil $\mathrm{pH}$ decline (over $0.3 \mathrm{pH}$ units within the past few decades) in Dinghushan than that in Xiqiaoshan (within 0.1 $\mathrm{pH}$ units within the past few years) coincided with the state of more nutrient impoverishment in the $0-10 \mathrm{~cm}$ depth soil in Dinghushan (Tab. I). Decline in the reconstructed soil pHs at the 10-40 cm depth was much slighter than that at the 0$10 \mathrm{~cm}$ depth at both sites, which was consistent with the relatively higher BS and exchangeable cations in the deeper soils (Tab. I).

Valid $\mathrm{pH}$ reconstruction should be verified against actual changes in soil $\mathrm{pH}$. The lack of long-term historical monitoring data on the soil chemistry in most cases created difficulty in validating the reconstruction. However, according to Berger et al. (2004), predictions based on soil chemistry could still be used to partially test their validity by the trend lines showing a general decline in soil $\mathrm{pH}$ with increasing stand age. Since most base cations were built into the stand's biomass 


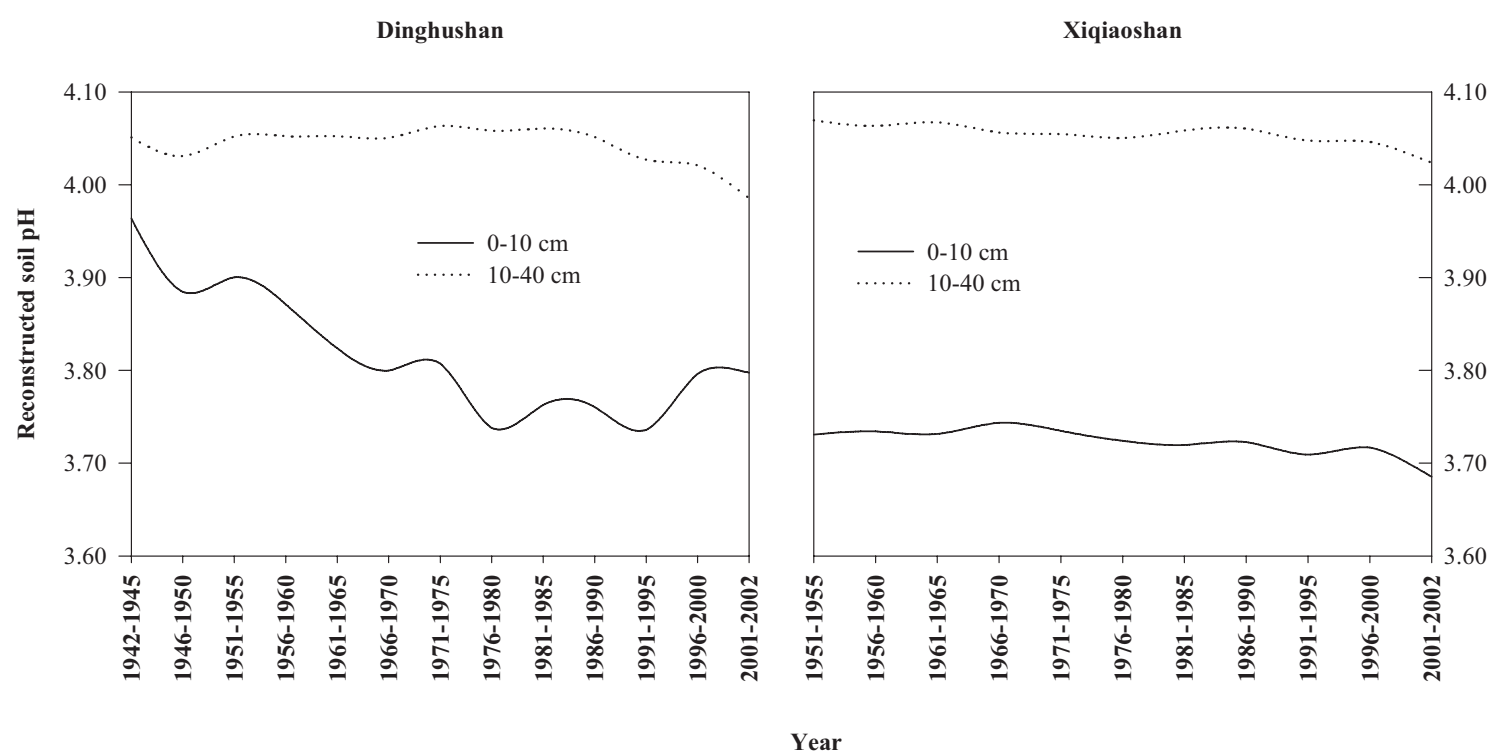

Figure 2. Mean reconstructed soil pH (1942-1945 to 2001-2002) from Masson pine growing in Dinghushan (solid line) and (1951-1955 to 2001-2002) in Xiqiaoshan (dotted line). Reconstructions were based on regressions of $\mathrm{Mg} / \mathrm{Mn}$ ratios and $\mathrm{Ca} / \mathrm{Mn}$ on soil pH at 0-10 $\mathrm{cm}$ and $10-40 \mathrm{~cm}$ depth, respectively.

as macronutrients, gradual acidification in the soil from the beginning to the end of a rotation period may occur. In this study, indirect verification of the soil $\mathrm{pH}$ reconstruction could also be accessed by: (i) Acid buffering capacity for the soils in Dinghushan was relatively poorer than for soils in Xiqiaoshan. This finding was in accordance with the results revealed in Table I and the results of Wen et al. (2000) and Liu et al. (2003). (ii) Acidifying impacts in Dinghushan were more pronounced than those in Xiqiaoshan, as already described by the exchangeable cations in the soils (Tab. I). (iii) The annual mean $\mathrm{pH}$ values of precipitation in the Delta steadily declined from 5.18 in 1985 to 4.48 in 2002 (Guangdong Environmental Protection Bureau, 2003).

\section{CONCLUSION}

Though single cations ( $\mathrm{Ca}, \mathrm{Mg}$ and $\mathrm{Mn})$ in tree rings of Masson pine were significantly correlated with the actual soil $\mathrm{pHs}$, the performance of linear regressions confirmed that cation molar ratios in the xylem of Masson pine were superior to the absolute simple cation concentration as indicators of soil $\mathrm{pH}$. Xylem ratios of $\mathrm{Mg} / \mathrm{Mn}$ and $\mathrm{Ca} / \mathrm{Mn}$ were useful indicators of soil chemistry at $0-10 \mathrm{~cm}$ and $10-40 \mathrm{~cm}$ depth, respectively. These results further justified $\mathrm{Mg} / \mathrm{Mn}$ and $\mathrm{Ca} / \mathrm{Mn}$ ratios in Masson pine could be potential indicators to examine long-term changes and to reconstruct soil acidification history on the medium time scale in the Pearl River Delta. Dendroanalysis of Masson pine provided an effective and simple determination for detecting soil chemistry changes in the external chemical environment and for giving early warning signals of the forest health. Periodic analysis of soils and tree-ring chemistry may provide direct verification for the reconstruc- tions and improve the accuracy when assessing the response of trees to soil acidification.

Acknowledgements: The project was jointly supported by the National Natural Science Foundation of China (No. 30570349, 30725006, 40730102), the Doctoral Foundation of the South China Botanical Garden (200606) and the Chinese Academy of Sciences Orientation Project (No. KSCX2-SW-120; KSCX2-SW-133).

\section{REFERENCES}

Augustin S., Stephanowitz H., Wolff B., Schröder J., and Hoffmann E., 2005. Manganese in tree rings of Norway spruce as an indicator for soil chemical changes in the past. Eur. J. For. Res. 124: 313-318.

Baes III C.F. and McLaughlin S.B., 1984. Trace elements in tree rings: evidence of recent and historical air pollution. Science 224: 494-497.

Berger T.W., Köllensperger G., and Wimmer R., 2004. Plant-soil feedback in spruce (Picea abies) and mixed spruce-beech (Fagus sylvatica) stands as indicated by dendrochemistry. Plant Soil 264: 69-83.

Bondietti E.A., Baes III C.F., and McLaughlin S.B., 1989. Radial trends in cation ratios in tree rings as indicators of the impact of atmospheric deposition on forests. Can. J. For. Res. 19: 586-594.

Campelo F., Nabais C., Freitas H., and Gutiérrez E., 2007. Climatic significance of tree-ring width and intra-annual density fluctuations in Pinus pinea from a dry Mediterranean area in Portugal. Ann. For. Sci. 64: 229-238.

Cronan C.S. and Grigal D.F., 1995. Use of calcium/aluminum ratios as indicators of stress in forest ecosystems. J. Environ. Qual. 24: 209226.

DeWalle D.R., Swistock B.R., Sayre R.G., and Sharpe W.E., 1991. Spatial variation in sapwood chemistry with soil acidity in Appalachian forests. J. Environ. Qual. 20: 486-491.

DeWalle D.R., Tepp J.S., Swistock B.R., Sharpe W.E., and Edwards P.J., 1999. Tree-ring cation response to experimental watershed acidification in West Virginia and Maine. J. Environ. Qual. 28: 299-309. 
Dong M., 1996. Survey, observation and analysis of terrestrial biocommunities. Standards Press of China, Beijing, $290 \mathrm{p}$.

Ferguson I.B. and Bollard E.G., 1976. The movement of calcium in woody stems. Ann. Bot. 40: 1057-1065.

Ferretti M., Innes J.L., Jalkanen R., Saurer M., Schäffer J., Spiecker H., and von Wilpert K., 2002. Air pollution and environmental chemistry what role for tree-ring studies? Dendrochronologia 20: 159-174.

Forget E. and Zayed J., 1995. Tree ring analysis for monitoring pollution by metals. In: Lewis T.E. (Ed.), Tree rings as indicators of ecosystem health. Boca Raton, CRC Press, Florida, pp.157-176.

Guan G.C. and Huang J.G., 2003. The space-time distribution characteristics of acid rain and its formation cause in Foshan city. J. Foshan Univ. 25: 68-70 (in Chinese with English abstract).

Guangdong Environmental Protection Bureau, 2003. Guangdong Province Environmental Quality Report. Guangzhou, China (In Chinese).

Guyette R.P. and Cutter B.E., 1994. Barium and manganese trends in treerings as monitors of sulfur deposition. Water Air Soil Pollut. 73: 213 223.

Guyette R.P., Henderson G.S., and Cutter B.E., 1992. Reconstucting soil $\mathrm{pH}$ from manganese concentrations in tree-rings. For. Sci. 38: 727 737.

Han S.S. and Liang J.P., 2001. The dynamic modeling of acidic deposition load on the ecosystem at Shaoguan. Environ. Sci. Tech. Suppl.: 10-12 (in Chinese with English abstract).

Hu D.Q. and Su X., 1999. Affects and loss evaluation of acid rain on the plants in Guangzhou area. Ecol. Sci. 18: 25-29 (in Chinese with English abstract).

Huang J.G., Guan G.C., and Li F., 2003. Study on distribution of pH value of rainfall in the atmosphere and causes of acid rain formation in Foshan city. J. Foshan Univ. 21: 54-57 (in Chinese with English abstract).

Jin L.H., 2002. Research on characteristics of acid rain and its effects on plants in Guangzhou area. Urban Environ. Urban Ecol. 15: 11-13 (in Chinese with English abstract).

Kashuba-Hockenberry L.A. and DeWalle D.R., 1994. Dendrochemical response to soil liming in scarlet oak. Can. J. For. Res. 24: 564-576.

Kogelmann W.J. and Sharpe W.E., 2006. Soil acidity and manganese in declining and nondeclining sugar maple stands in Pennsylvania. J. Environ. Qual. 35: 433-441.

Kuang Y.W., Sun F.F., Wen D.Z., Zhou G.Y. and Zhao P., 2008. Tree-ring growth patterns of Masson pine (Pinus massoniana L.) during the recent decades in the acidification Pearl River Delta of China. For. Ecol. Manage. 255: 3534-3540.

Kuang Y.W., Wen D.Z., Zhou G.Y., and Liu S.Z., 2007. Distribution of elements in needles of Pinus massoniana (Lamb.) was uneven and affected by needle age. Environ. Pollut. 145: 146-153.

Kurczyńska E.U., Dmuchowski W., Włoch W., and Bytnerowicz A., 1997. The influence of air pollutants on needle and stems of Scots Pine (Pinus sylvestris L.) trees. Environ. Pollut. 98: 325-334.

Lévy G., Bréchet C., and Becker M., 1996. Element analysis of tree rings in pedunculate oak heartwood: an indicator of historical trends in the soil chemistry, related to atmospheric deposition. Ann. For. Sci. 53: 685-696.

Liu J.X., Zhang D.Q., Zhou G.Y., Wen D.Z., and Zhang Q.M., 2003. Preliminary study on the chemical properties of bulk precipitation, through fall, stem flow and surface water in major forest types at Dinghushan under acid deposition. Chinese J. Appl. Ecol. 14: 1223-1228 (in Chinese with English abstract).

Luo S.S., Wu Z.M., Xu Y.G., Zhou G.Y., and He Z.C., 2001. Preliminary studies on the effects of atmosphere pollution on forest and soil in Pear River Delta, China. Ecol. Sci. 20: 11-16 (in Chinese with English abstract).

Meerts P., 2002. Mineral nutrient concentrations in sapwood and heartwood: a literature review. Ann. For. Sci. 59:713-722.

Muzika R.M., Guyette R.P., Zielonka T., and Liebhold A.M., 2004. The influence of $\mathrm{O}_{3}, \mathrm{NO}_{2}$ and $\mathrm{SO}_{2}$ on growth of Picea abies and Fagus sylvatica in the Carpathian Mountains. Environ. Pollut. 130: 65-71.

Neubauer C., 2000. Vergleich des Waldbodenzustandes sekundärer Fichtenreinbestände mit Mischbeständen in der Flyschund Molassezone auf Untersuchungsflächen des SFB Waldökosystemsanierung. Diploma Thesis. Univ. f. Bodenkultur, Wien, $122 \mathrm{p}$.

Orlandi M., Pelfini M., Pavan M., Santilli M., and Colombini M.P., 2002. Heavy metals variations in some conifers in Valle d'Aosta (West Italian Alps) from 1930 to 2000. Microchem. J. 73: 237-244.

Padilla K.L. and Anderson K.A., 2002. Trace element concentrations on tree-rings biomonitoring centuries of environmental change. Chemosphere 49: 575-585.

Park Y., Dallaire G., and Morin H., 2006. A method for multiple intra-ring demarcation of coniferous trees. Ann. For. Sci. 63: 9-14.

Penninckx V., Glineur S., Gruber W., Herbauts J., and Meerts P., 2001. Radial variations in wood mineral element concentrations: a comparison of beech and pedunculate oak from the Belgian Ardennes. Ann. For. Sci. 58: 253-260.

Poszwa A., Wickman T., Dambrine E., Ferry B., Dupouey J.-L., Helle G., Schleser G., and Breda N., 2003. A retrospective isotopic study of Spruce decline in the Vosges mountains (France). Water Air Soil Pollut. Focus 3: 201-222.

Punshon T., Lanzirotti A., Harper S., Bertsch P.M., and Burger J., 2005. Distribution and speciation of metals in annual rings of black willow. J. Environ. Qual. 34: 1165-1173.

Saurer M., Cherubini P., Ammann M., Cinti B.D., and Siegwolf R., 2004. First detection of nitrogen from $\mathrm{NO}_{\mathrm{x}}$ in tree rings: ${ }^{15} \mathrm{~N} /{ }^{14} \mathrm{~N}$ study near a motorway. Atmos. Environ. 38, 2779-2787.

Smith K.T. and Shortle W.C., 1996. Tree biology and dendrochemistry. In: Dean J.S. et al. (Eds.), Tree rings, environment and humanity, Tucson, AZ, USA, pp. 629-635.

Taylor G.L., 1988. The physiology of aluminum tolerance in higher plants. Commun. Soil Sci. Plan. 19: 1179-1194.

Watmough S.A., 1997. An evaluation of the use of dendrochemical analyses in environmental monitoring. Environ. Rev. 5:181-201.

Wen D.Z., Kuang Y.W., Liu S.Z., Zhang D.Q., Lu Y.D., and Li J.L., 2006. Evidences and implications of vegetation damage from ceramic industrial emission on a rural site in the Pearl River Delta of China. J. For. Res. 17: 7-12.

Wen D.Z., Zhou G.Y., Kong G.H. and Yu M.D., 2000. A status report on the effects involved with acid rain on plants, soils and surface waters of three selected terrestrial ecosystems in lower subtropical China. Chinese J. Ecol. 19: 11-18 (in Chinese with English abstract).

Xie W.Z., Li Z.Y. and Zhong C.Q., 2002. Study of acid rain pollution and control in Guangdong province. Chongqing Environ. Sci. 24: 64-66 (in Chinese with English abstract).

Yilmaz S. and Zengin M., 2004. Monitoring environmental pollution in Erzurum by chemical analysis of Scots pine (Pinus sylvestris L.) needles. Environ. Int. 29: 1041-1047. 